only the purely voluntary muscles in micturition. There is evidently a diminution of the peripheral stimulus reaching the reflex centre in the cord. This case, so far as pathological evidence affords proof for physiological conditions, certainly points in favour of the theory that the detrusor urinæe is purely reflex in its function. To me the rationale of the process in this case is as follows: The patient feels slightly the call to micturate. He assumes a position which least obstructs the egress of urine. He strains and patiently empties the bladder. The detrusor does not act here, for, observe, the flow is weak and stops whenever he speaks. Now, when he alters his position by sitting on his haunches, opens his legs, passes his finger into the rectum, and thus sets up an additional stimulation (the vesical distension not being sufficiently strong in its stimulation of the reflex centre of the detrusor, owiog to one-half of the nerves not reaching the centre), this rectal stimulation is sufficiently powerful to set up the contraction of the detrusor. Note his inability to tell from urethral insensibility that the urine flows. In this case the flow is strong, indicating the contraction of the detrusor. In like manner the rectum cannot naturally be emptied. It, like the detrusor, is only under reflex control. By exercise of the abdominal voluntary museles substances lodged in the rectum cannot be voided, as found hy experiment. So here there is also a diminution of the ordinary stimulation reaching the centre for the rectum. The patient there'ore takes a purgative, and the liquid motion thus produced being more irritating, the deficiency in the stimulation is compensated, and the rectum refiexly contracts and expels its contents.

Burnley, Lancashire.

\section{ON THE USE OF}

\section{JABORANDI OR PILOCARPINE IN THE COL-} LAPSE OF SCARLATINA MALIGNA.

BY ROBERT P ARK, M.D. \&C.,

PHYSICIAN FOR DISEASES OF WOMEN AND ChILDREN at aNDERSON'S COLLEGE DISPENSARY, ETC.

ON March 3rd I was sent for to see A. S_- aged five years, who had been ssized suddenly, early on the morning of the previous day, with violent vomiting and purging. Nothing would "lie on his stomach" even water, the mother said. When I saw him he exhibited all the objective symptoms of collapse. He moaned occasionally, "Oh, my belly." There was also the characteristic smell which exhales from the body of many patients with enteric or scarlet fevers. In the present case diagnosis was impozsible. I inclined, however, to the belief that it was a case of scarlatina malizna, the suason of the year and the history putting cholera out of the question, and such a sudden onset being very unusual for enteric. Moreover, the abdomen was flaccid and flabby. Temperature in axilla 101 $5^{\circ}$; pulse 160 . I ordered half a teasp onful of brandy every hour, and the following mixture:-Liquid extract of jaborandi, three drachms (R ch.erdson' $*$ ); solution of acetate of ammonia, two ounces; syrup of poppies, four drachms; chloroform water to four ounces. A teaspooufal every two hours.

March 4th. - This day the child was very much in statu quo. However, purging had ceased, though he was sick, and vomited occasionally. He had scarcely passed any water during the last twenty-four hours. Eyes half opened and glazed. Temperature in flexure of thigh, $96^{\circ}$. Dose of jaborandi doubled, and to be given every hour. Enema of turpentine and beef-tea; milk and soup and brandy ad libitum. Hot mustard applications were ordered also to the calves of the legs and feet, and to the abdomen. After a few hours, there being no signs of the physiological action of the jaborandi, unless, perhaps, a slight increase of strength in pulse, I gave him a few drops of amyl nitrite to suiff. This gave a temporary fillip to the heart, but he soon relapsed into a semi-comatose condition, and it seemed as if death was going to be the issue. Thoroughly satisfied, however, that jaborandi was the remedy if it could only be got into circulation, I had Bome fresh solution of the active principle (pilocarpine) prepared and injected hypodermically, one-thirtieth of a grain, into the inner surface of the thigh, and this failing to produce any characteristic phenomena, I injected another one-thirtieth into the arm about twenty minutes afterwards
This produc $<$ an immediate improvement in the pulse, and he became more restless, and in a short time asked to be lifted, when a copious flow of clear urine was passed, together with a watery stool, dark brown in colour. None of the characteristic phenomena of pilocarpine were produced.5th: The child has neither vomited nor purged during the night, but has passed water. There is a slight flush on the face; no sweating; no ptyalism; extremities not so cold; respiration no longer sighing; pulse 140, and of better tone; ears warm; eyes no longer glazed; and upon the whole reaction, though faint, may be said to be fairly established. Treatment continued. -6th : Reaction complete, but not excessive. Pulse 140 ; temperature $102^{\circ}$. Tth: None of the symptoms peculiar to either enteric or scarlet fevers have made their appearance, but the strong fever smell is no longer obtrusive. - 10th and 11th: The pulse still keeps quick, 140 ; temperature from $101^{\circ}$ to $102^{\circ}$. The very thick creamy fur which has completely hidden the tongue for the last two days completely exfoliated to-day (11th), and has left the tongue raw and clean, and so tender that hardly anything can be borne by it. The same thing seems also to have happened with the stomach, as the little fellow positively screams when food enters it. -12 th : The child is comparatively well to-day, but his pulse still keeps to 140 , and he is very weak. He has also bad, in answer to a small dose of castor oil, two stools of a tarry description. The urine examined on the 15 th was normal iu all respects, there being neither albumen nor tube casts present.

Remarks. - This case offers some special features for consideration-namely, the completeness and prolonged duration of the collapse, the exfoliation of the gastro-intestinal mucus, and the limited duration of the entire illness (eight days). The only case at all parallel with it that I have met with was at Stewarton, Ayrshire. It occurred in a boy, about six years old, the last of a family of four to take the fever. The vomiting, purging, and collaose, however, were of short duration, and a faint rash did appear on the skin, and recovery followed. The etiology of this case is very obscure, as no scarlet fever is known of in the neighbourhood, I am informed by favour of Dr. Russell. This fact, taken with that of recovery, makes me almost think it may have been an acute gastro-bilious attack, or acute gastro-intestinal catarrh; but then the sudden onser, peculiar odour, pyrexia even during collapse, suppression of urine, and desquamation of gastro-intestinal mucus, appear to negative this idea. $M y$ theory is of course that the exanthem was determined to the $g$ istro-intestinal su $f_{1}$ ce, there causing complete suspension of all alimentation and rejection of the contents of the alimentary canal, and subsequent desquamation of the mucous membrane. In fact it became an endanthem, and in this connexion it may be mentioned that the winds have been unu=ually bitterly cold and piercing here since March came in. The urine was not examined till the 16th, when it was found to be in all respects normal, and at this date the child is slowly gain. ing strength, though not yet able to walk. Glasgow.

\section{d attirror \\ or}

\section{H.O S P I T A L P R A C T I C E,}

\section{BRITISH AND FOREIGN.}

Nu.la autem est alia pro certo noscendi via, nisi quamplurimas et morborum et dissectionum historias, tum aliomm tam proprias collectas habere, et inter se comparare.-MoвGAGNI De Sed. et Caus. Morb., lib. iv. Procemium.

\section{MIDDLESEX HOSPITAL.}

ACUTE PHOSPHORUS POISONING; NECROPSY.

(Under the care of Dr. W. CAYLEY.)

FOR the notes of the following case we are indebted to Mr. S. R. Dyer, physician's assistant :-

A. F-, a healthy, well-nourished girl, aged eighteen, was admitted into the hospital on Monday, April 15th, at 3 P M. She stated that she had on the Thursday (April 11th) preceding taken two penny bottles of phosphorus paste with suicidal intent.

The mother of the girl stated that the father had died in a 